\title{
Metabolism of nitrogen and sulfur in ectosymbiotic bacteria of marine nematodes (Nematoda, Stilbonematinae)
}

\author{
U. Hentschel ${ }^{1, *}$, E. C. Berger ${ }^{2}$, M. Bright ${ }^{2}$, H. Felbeck ${ }^{3}$, J. A. Ott ${ }^{2}$ \\ 'Institut für Molekulare Infektionsbiologie, Universität Würzburg, Röntgenring 11, D-97070 Würzburg, GermanY \\ ${ }^{2}$ Institut für Zoologie, Universität Wien, A-1090 Vienna, Austria \\ ${ }^{3}$ Marine Biology Research Division, Scripps Institution of Oceanography, La Jolla, California 92093, USA
}

\begin{abstract}
Nematodes of the family Stilbonematinae are known for their highly specific association with ectosymbiotic bacteria. These worms are members of the meiofauna in marine, sulfide-rich sediments, where they migrate around the redox boundary layer. In this study, bacterial ectosymbionts of 2 species of marine nematodes, Stilbonema sp. and Laxus oneistus, were shown to be capable of the respiratory reduction of nitrate and nitrite (denitrification). The use of these alternative electron acceptors to oxygen by the bacteria allows the animals to migrate into the deeper, anoxic sediments, where they can exploit the sulfide-rich patches of the deeper sediment layers. The accumulation of thiols (sulfide, thiosulfate, sulfate and glutathione) in body tissues of the worms was determined following incubation in the presence of various electron donors (sulfide, thiosulfate) and acceptors (nitrate). In their chemoautotrophic metabolic potential, the ectosymbionts of the 2 nematode species were found to resemble the phylogenetically related, intracellular symbionts of macrofaunal hosts of deep-sea hydrothermal vents and other sulfide-rich habitats.
\end{abstract}

KEY WORDS: Stilbonematinae $\cdot$ Symbiosis $\cdot$ Chemoautotrophy $\cdot$ Sulfide $\cdot$ Denitrification

\section{INTRODUCTION}

Stilbonematinae (Nematoda, Desmodorida) are a small subfamily of marine, free-living nematodes, which are remarkable for their highly specific, obligatory association with ectosymbiotic bacteria. Worms of this family are members of the meiofaunal community inhabiting sulfide-rich sands, where they are found to cluster around the redox potential boundary layer $(\mathrm{Ott}$ \& Novak 1989, Ott et al. 1991). Their habitat is characterized by the simultaneous access to sulfide, which is microbially produced through the action of anaerobic, sulfate-reducing bacteria, and to oxygen, which is mixed into the sediments from the overlying ocean water (Fenchel \& Riedl 1970). The result is a complex 3-dimensional redox landscape, which is variable both

\footnotetext{
•E-mail: ute.hentschel@mail.uni-wuerzburg.de
}

in time and space. Sulfide and oxygen are toxic to all organisms, the former through its reversible inhibition of the enzyme cytochrome c oxidase at even nanomolar concentrations and the latter through the formation of oxygen radicals, such as the hydroxyl radical $\left(\mathrm{OH}^{-}\right)$ and hydrogen peroxide $\left(\mathrm{H}_{2} \mathrm{O}_{2}\right)$. In the natural habitat, sulfide concentrations of up to several $\mathrm{mM}$ have been measured in patches whereas oxygen is generally depleted below the first few $\mathrm{cm}$ of sediment depth. The animals inhabiting these environments are known to possess strategies to overcome the toxic effects of sulfide, including enzymatic and non-enzymatic detoxification mechanisms as well as mechanisms for sulfide exclusion (Somero et al. 1989, Vismann 1991).

In contrast to most nematodes, which are remarkably free of epigrowth, stilbonematid worms are covered with a dense bacterial coat in a species-specific and highly structured manner. So far, 3 different types of bacterial coats have been described. Worms of the 
genera Stilbonema and Leptonemella have a multilayered coat of coccoid bacteria (Ott et al. 1991, Polz et al. 1992). The bacterial coat of the genera Laxus, Robbea and Catanema is a monolayer of rod-shaped bacteria, which are individually attached to the worms' cuticule. The third type of bacterial coat is seen in worms of the genus Eubostrichus where the filamentous bacteria are up to $100 \mu \mathrm{m}$ long (Polz et al. 1992, Berger et al. 1996). Representatives of the described genera and several other symbiotic meiofaunal inhabitants are found at the collection site on Carrie Bow Cay, Belize, Central America.

In addition to the morphological characterizations, biochernical studies have confirmed the chemoautotrophic nature of symbionts (Polz et al. 1992). The identification of key enzymes, such as RUBISCO (ribulose 1,5 bisphosphate carboxylase/oxygenase), points towards autotrophic $\mathrm{CO}_{2}$ fixation via the Calvin Benson cycle. The presence of the enzymes ATP-sulfurylase and sulfite oxidase combined with the presence of high amounts of elemental sulfur in the tissues of these worms provide strong evidence for the ability to generate energy from reduced sulfur compounds. Thirdly, nitrate reductase activity was measured in the worms. However, whether this is of assimilatory or dissimilatory (respiratory) function has not been determined. Moreover, physiological studies addressing the rate of oxygen respiration have shown that the respiration rate can be significantly stimulated by sulfide (Schiemer et al. 1990). This was taken as an indication that sulfide serves as an energy source for these symbioses.

The phylogenetic identity of the bacteria of Laxus oneistus has been elucidated using the 16S rRNA approach combined with in situ hybridization techniques (Polz et al. 1994). It was shown that the symbionts of $L$. oneistus form the base of a phylogenetic cluster including chemoautotrophic symbionts of $3 \mathrm{bi}$ valve families and of the deep-sea hydrothermal vent tube worm Riftia pachyptila. None of the bacteria from this taxonomic cluster have been cultured to this date. These studies confirmed also that the bacterial coat of $L$. oneistus consists of a bacterial monoculture, a speculation which had been made previously based on the strikingly uniform morphology of the bacterial coat.

Several hypotheses about the benefit the worms may derive from this symbiotic interaction exist. It has been proposed that the worms obtain most of their nutrition by grazing on their epibionts (Wieser 1959, Ott \& Novak 1989, Ott et al. 1991). Supporting evidence comes from TEM observations which show bacteria in the gut of the animals similar to those seen on the cuticle (Ott et al. 1991). A nutritional benefit of the symbionts to the host was confirmed using stable carbon isotope ratios (Ott et al. 1991). The low isotope signature of aposymbiotic stilbonematid worms compared to other nonsymbiotic nematodes implies that they must live almost exclusively off their chemoautotrophic bacteria.

The following study aims to further characterize the chemoautotrophic potential of these symbioses with specific emphasis on the metabolism of nitrogen and sulfur. A second goal was to elucidate the interaction between bacteria and hosts with the specific focus on the nature of the bacterial coat.

\section{METHODS}

Animal collection. This study was performed at the Smithsonian Field Station on Carrie Bow Caye, an island located on the Belize Barrier Reef, Central America $\left(16^{\circ} 48^{\prime} \mathrm{N}, 88^{\circ} 05^{\prime} \mathrm{W}\right)$. Stilbonematids were collected from a coral sand bar at the north end of the island between 30 and $50 \mathrm{~cm}$ depth (Ott \& Novak 1989). Approximately 51 of sediment were collected with a bucket and the worms were extracted by gently shaking $200 \mathrm{ml}$ portions in seawater and pouring the supernatant through a $63 \mu \mathrm{m}$ mesh screen. The worms were handpicked with the aid of a dissecting microscope and sorted according to species. Laxus oneistus and Stilbonema sp. were among the most abundant species of the nematode meiofauna, but infrequently, other symbiont-containing worms were also found. Batches of 50 worms were then transferred into watch glasses with glassbeads in order to prevent clumping of the worms, due to their thigmotactic behaviour.

Nitrate respiration. Following collection, the worms were maintained overnight in seawater, which greatly improved the reproducibility of the data. Unless otherwise stated, batches of 100 specimens were incubated in HPLC glass scintillation vials plus glass beads containing $5 \mathrm{ml}$ of $0.2 \mu \mathrm{m}$ filtered seawater at ambient temperature (approx. $30^{\circ} \mathrm{C}$ ). The seawater had been degassed with $\mathrm{N}_{2}$ gas for 30 min prior to use. At intervals, $300 \mu \mathrm{l}$ aliquots were withdrawn with a syringe under a constant stream of $\mathrm{N}_{2}$ and subsequently analyzed as described below. The rates of nitrate and nitrite respiration were measured after addition of nitrate $(50 \mu \mathrm{M}, 100 \mu \mathrm{M}, 1 \mathrm{mM})$ or nitrite $(40 \mu \mathrm{M})$ to the incubation medium. Stimulation of nitrate respiration by thiols was measured in batches of 25 worms in seawater containing $1 \mathrm{mM}$ nitrate after addition of sulfide or thiosulfate to a final concentration of $200 \mu \mathrm{M}$. Here, the nitrite standard curve was prepared in the presence of $200 \mu \mathrm{M}$ sulfide or $200 \mu \mathrm{M}$ thiosulfate. Nitrate respiration in white versus pale worms was measured in batches of 25 worms in seawater containing $1 \mathrm{mM}$ nitrate. Several other symbiotic nematodes from the Carrie Bow Cay sandbar were also tested for their ability to respire nitrate. The incubations were performed 
in Eppendorf tubes containing $100 \mu \mathrm{l}$ degassed seawater with $1 \mathrm{mM}$ nitrate. Individual worms were added under a constant stream of $\mathrm{N}_{2}$ and the concentration of nitrite was determined after $24 \mathrm{~h}$ in the supernatant.

The concentration of nitrite was measured spectrophotometrically at $543 \mathrm{~nm}$ after reaction with sulfanilamide ( $1 \%$ in $1 \mathrm{~N} \mathrm{HCl})$ and NED $(0.01 \%$ [w: $\mathrm{v}]$ $\mathrm{N}$-[1-napthyl]-ethylene-diamine dihydrochloride). The concentration of nitrate was determined after reduction to nitrite with a flow-through column containing copper-coated cadmium chips (Gieskes \& Peretsman 1986). The concentration of oxygen was measured with a polarographic oxygen sensor (YSI Instruments). The calibration of the sensor was carried out with air-saturated seawater and with seawater made anoxic by addition of sodium sulfite. The spectrophotometric determination of sulfide was performed following the method of Cline (1969).

Oxidation of thiols. Following $24 \mathrm{~h}$ maintenance in microoxic seawater ( $<20 \%$ oxygen conc.), the worms were transferred into $5 \mathrm{ml}$ incubation vials containing anoxic seawater to which different electron donors (200 $\mu \mathrm{M}$ sulfide, $1 \mathrm{mM}$ thiosulfate) and electron acceptors ( $1 \mathrm{mM}$ nitrate) had been added. After $6 \mathrm{~h}$ incubation, batches of 20 Stilbonema sp. or 50 Laxus oneistus were removed, homogenized in the respective buffers and stored in liquid $\mathrm{N}_{2}$. The concentrations of sulfide, thiosulfate, sulfate, oxygen in the incubation medium were determined at the beginning and end of each experiment.

Internal sulfide, thiosulfate and glutathione concentrations were determined by HPLC in the laboratory of Professor Grieshaber, Heinrich-Heine University in Düsseldorf, Germany, after Fahey \& Newton (1987). The homogenisation buffer (160 mM HEPES, $16 \mathrm{mM}$ EDTA, pH 8.0) contained acetonitrile (50\%) and monobromobimane ( $3 \mathrm{mM}$ ) which had been added to the buffer immediately prior to homogenisation. After a 30 min storage period of the samples in the dark, 1 part methanesulfonic acid ( $30 \mathrm{mM}$ final conc.) was added and the samples were frozen in liquid $\mathrm{N}_{2}$. The HPLC analyses were carried out on a L-6200 Intelligent Pump high-performance liquid chromatograph (MerckHitachi), equipped with a Fluorescence Spectrophotometer F-1050 (Merck/Hitachi) with $380 \mathrm{~nm}$ excitation/480 nm emission filters; the data were processed with a Merck-Hitachi MODEL 0-6000 Chromatography (Data Station Software). For separation a Merck LiChrospher $60 \mathrm{RP}$-select B column with $5 \mu \mathrm{m}$ particle size and $12.5 \mathrm{~cm}$ length was utilized.

The sulfate concentration was determined by IonChromatography (Koop 1984). The animals were fixed with $30 \mu$ acetonitrile and formaldehyde $(2 \%$ final concentration), homogenized in a $100 \mu \mathrm{l}$ glass microhomogenizer and stored in liquid $\mathrm{N}_{2}$. The samples were centrifuged immediately before analysis for $15 \mathrm{~min}$ at $14500 \times \mathrm{g}$. All analyses were carried out on a Dionex (DX-100) Ion-Chromatograph (Dionex, Sunnyvale, USA) with a DIONEX AS-4a column, a AG4a precolumn at room temperature. The solvent consisted of $\mathrm{Na}_{2} \mathrm{CO}_{3}(1.8 \mathrm{mM})$ and $\mathrm{NaHCO}_{3}(1.7 \mathrm{mM})$ and was pumped with a flow rate of $1.8 \mathrm{ml} \mathrm{min}^{-1}$. To attain a low baseline conductivity a DIONEX micromembrane suppressor AMMS 1 with $\mathrm{H}_{2} \mathrm{SO}_{4}(25 \mathrm{mM})$ as regenerens was used. Detection was carried out with a bipolar pulsed conductivity cell (active volume $=1.25 \mu l$ ). Calibration was performed with a standard solution of 0.05 and $0.5 \mathrm{mM} \mathrm{Na} \mathrm{SO}_{4}$.

Statistical analyses of significance regarding the internal thiol concentrations after different incubation conditions were performed using the the Student's $t$-test (unpaired, 2 -tailed with $\mathrm{p}<0.05 \%$ ). In order to determine the percentage of sulfide and thiosulfate in the worms' bodies and in the bacterial coats, the mean values of the biometrical data (Wieser 1960, Schiemer et al. 1990) were used.

Determination of metabolic rates. The rates of nitrate and nitrite respiration were calculated from the data presented in Fig. 1. The rate of sulfide oxidation
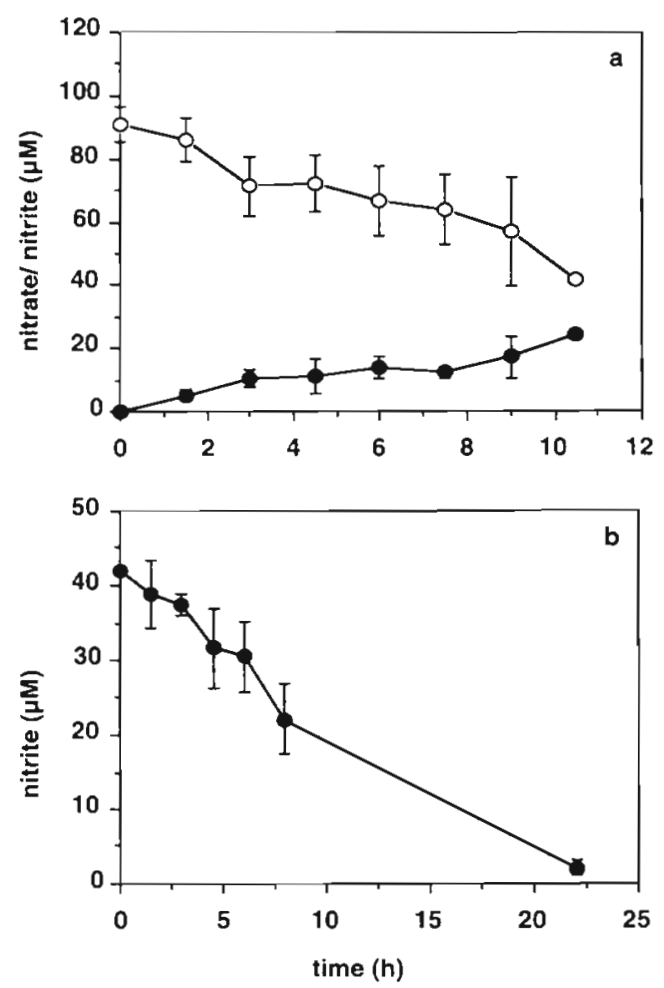

Fig. 1. Stilbonema sp. (a) Average rates of (o) nitrate consumption and $(\bullet)$ nitrite production in anaerobic incubations containing $100 \mu \mathrm{M}$ nitrate of 100 Stilbonema worms each $(\mathrm{n}=3 \pm \mathrm{SE}$ ). (b) Average rates of nitrite consumption ( $\bullet$ ) in anaerobic incubations containing $42 \mu \mathrm{M}$ nitrite $(\mathrm{n}=3 \pm \mathrm{SE}$ ) 
was measured in the presence of $200 \mu \mathrm{M}$ sulfide and $1 \mathrm{mM}$ nitrate in incubations of 100 worms $(\mathrm{n}=3$, data not shown). The rate of sulfide loss due to chemical oxidation was determined in incubations without worms and was subtracted out as the background. Four aliquot samples were taken over the course of $10 \mathrm{~h}$ and the concentration of sulfide was determined spectrophotometrically. The rate of $\mathrm{CO}_{2}$ fixation was determined after addition of $100 \mu \mathrm{Ci} \mathrm{NaH}{ }^{14} \mathrm{CO}_{3} \mathrm{ml}^{-1}$ to incubations of 20 worms in an incubation volume of $0.5 \mathrm{ml}$ seawater containing $1 \mathrm{mM}$ nitrate. At time intervals of 2,4 and $8 \mathrm{~h}$, batches of worms were homogenized in a glass homogenizer in $100 \mu \mathrm{l} 0.6 \mathrm{M} \mathrm{HClO}_{4}$ and frozen in liquid $\mathrm{N}_{2}$. The samples were then evaporated under a fumehood, neutralized by addition of $\mathrm{KOH}$, centrifuged at $10000 \times g$ for $15 \mathrm{~min}$ and the radioactivity was counted in a liquid scintillation counter.

Symbiont culture. Samples containing symbiotic bacteria which had been stripped off Laxus oneistus and Stilbonema sp. worms were stored in 15\% sterile glycerol at $-80^{\circ} \mathrm{C}$. Upon return to the laboratory, $3 \mathrm{ml}$ cultures of Zobell marine media were inoculated and shaken at room temperature $\left(21^{\circ} \mathrm{C}\right.$ ) (D. Hughes pers. comm.). Stationary phase cultures were plated on Zobell Marine Agar plates (Difco 2216). Following single colony isolation, chromosomal DNA was extracted using standard phenol-chloroform protocols and precipitated with EtOH. The closer examination of the $16 \mathrm{~S}$ rRNA gene sequence of the isolates by PCR amplification of the $16 \mathrm{~S}$ rRNA gene fragment with universal primers and sequence analysis confirmed that none of the isolates were symbionts of either $L$. oneistus or Stilbonema sp. (Martin Polz pers. comm.).

Worm recolonisation experiments. The bacterial coat of Laxus oneistus was removed by a $30 \mathrm{~min}$ incubation in $5 \mathrm{ng} \mathrm{m}^{-1}$ benzalkonium chloride (Zephirol, BayerLeverkusen). The bacterial coat of Stilbonema sp. was removed by sonification with $3 \times 10 \mathrm{~s}$ pulses of the lowest setting. The animals retained $<5 \%$, estimated by eye, of the original coat and survived the sonification treatment without apparent signs of damage. Worms from which the coat has been mechanically removed are herein called 'aposymbiotic'. The dye safranine-o-chloride stained the bacterial coat selectively red and was used for visualisation of the different treatments.

After visual inspection, animals with different degrees of coat loss ranging from about $<5$ to $>80 \%$, estimated by eye, were used. They were placed in $96-$ well microtiter dishes which were filled with glass beads or with sand grains from their habitat. The dishes were then placed in $10 \mathrm{l}$ buckets which had been half filled with sand, and into which a hose with running seawater had been placed. A few crystals of sulfide were placed into the sand as a sulfide source. In addition, worms which already had small holes in the coat after collection were used in order to control for possible damage following sonification or treatment with detergents. Single worms as well as groups of 2 to 3 worms were placed into each well. Different types of water, such as surface seawater, porewater from the collection site or seawater containing symbiotic bacteria were added to the incubation wells. The condition of the worms was inspected daily under a dissecting microscope and under a light microscope for $7 \mathrm{~d}$.

\section{RESULTS}

\section{Nitrate respiration}

When Stilbonema sp. worms were incubated anaerobically in the presence of $100 \mu \mathrm{M}$ nitrate, nitrite appeared in the incubation medium at a rate of $6.2 \mu \mathrm{mol}$ nitrite $\mathrm{g}^{-1}$ wwt $\mathrm{h}^{-1}(\mathrm{n}=3 \pm \mathrm{SE}$ ) (Fig. 1a, Table 1). Essentially the same rate was obtained in a concentration of $50 \mu \mathrm{M}$ nitrate ( $\mathrm{n}=3$, data not shown). When incubations were done without worms $(n=3)$, or without nitrate ( $\mathrm{n}=3$ ), nitrite was not formed. Also, when nonsymbiotic nematodes of approximately the same size from the same habitat were used, nitrite was not formed. Moreover, nitrite was not formed in the presence of inhibitors of the respiratory chain, azide $(150 \mu \mathrm{M}, \mathrm{n}=1)$ or cyanide (5 mM, $\mathrm{n}=1)$. Nitrite was formed at a much lower rate under aerobic conditions $\left(0.2 \mu \mathrm{mol}\right.$ nitrite $\left.\mathrm{g}^{-1} \mathrm{wwt} \mathrm{h}^{-1}\right)$ in 2 out of 3 incubations (data not shown).

The conversion of nitrate to nitrite was not stoichiometric, i.e. more nitrate was consumed than nitrite was formed. When stilbonematid worms were incubated in the presence of nitrite, it disappeared at a rate of $2.2 \mu \mathrm{mol} \mathrm{g}{ }^{-1}$ wwt $\mathrm{h}^{-1}$ (Fig. $1 \mathrm{~b}$, Table 1). Nitrite did not disappear in the absence of worms $(n=3)$. The rate of nitrate respiration was higher in white animals than in pale animals (Fig. 2). In Stilbonema sp., sulfide or thiosulfate did not stimulate nitrate respiration under the given experimental conditions (Fig. 3a). An inverse correlation was observed between the rate of nitrate respiration and the numbers of worms per experiment.

Table 1. Stilbonema sp. and Laxus oneistus. Comparison of metabolic rates. nd: not determined

\begin{tabular}{|lcc|}
\hline Metabolic pathway & $\begin{array}{c}\text { Stilbonema } \mathrm{sp} . \\
\left(\mu \mathrm{mol} \mathrm{g}^{-1}\right.\end{array}$ & $\begin{array}{c}\text { Laxus oneistus } \\
\left.\text { wwt h}^{-1}\right)\end{array}$ \\
\hline Nitrate respiration & 6.2 & 3.9 \\
Nitrite respiration & 2.2 & 4.4 \\
Sulfide oxidation & 2.5 & nd \\
Carbon fixation & 1.8 & nd \\
\hline
\end{tabular}




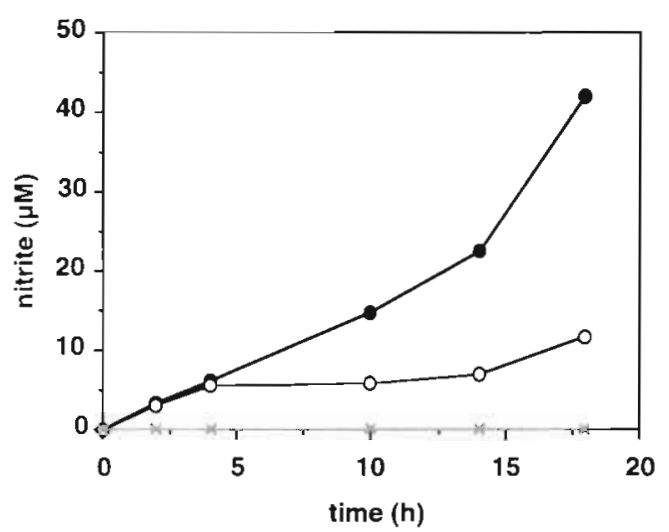

Fig. 2. Stilbonema sp. Average rates of nitrate respiration in anaerobic incubations of 25 Stilbonema worms of ( ) white or

(o) pale color appearance $(n=2)$ or (") without worms

Higher nitrate respiration rates were obtained with 25 worms $5 \mathrm{ml}^{-1}$ incubation volume (Fig. 3a) than with 100 worms $5 \mathrm{ml}^{-1}$ incubation volume or 200 worms $5 \mathrm{ml}^{-1}$ incubation volume (data not shown). Therefore the calculated rates (Fig. 1. Table 1) are likely to be underestimates of the true metabolic potential.
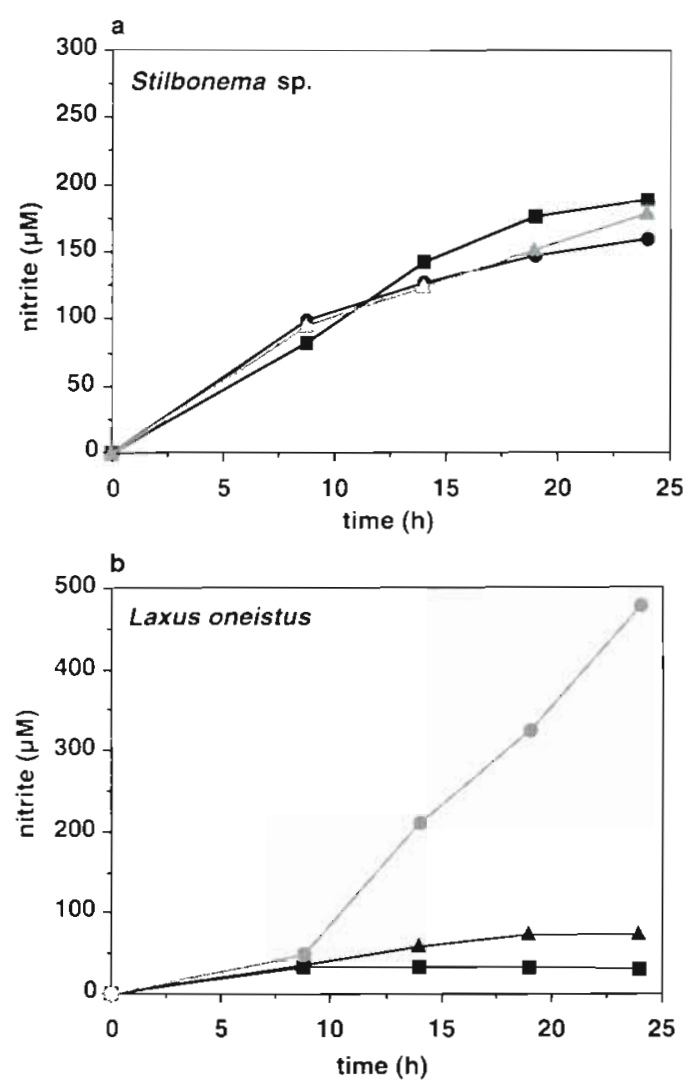

Fig. 3. Thiol stimulation of nitrate respiration in (aj Stilbonema sp. and in (b) Laxus oneistus. (•) $200 \mu \mathrm{M}$ sulfide, (4) $200 \mu \mathrm{M}$ thiosulfate or ( $(\mathbf{m o}$ ) thiols added, $(\mathrm{n}=2)$
When batches of 100 Laxus oneistus were incubated anaerobically in the presence of nitrate $(50,100 \mu \mathrm{M})$, nitrite appeared at a rate of $3.9 \mu \mathrm{mol} \mathrm{g}{ }^{-1} \mathrm{wwt} \mathrm{h} \mathrm{h}^{-1}$ $(n=3)$, (Table 1). When incubated in nitrite $(40 \mu \mathrm{M})$, it disappeared at a rate of $4.4 \mu \mathrm{mol} \mathrm{g}^{-1}$ wwt $\mathrm{h}^{-1}(\mathrm{n}=3)$, (Table 1). Nitrate respiration was stimulated by sulfide but not by thiosulfate (Fig. 3b).

Nitrite was produced by Stilbonema sp. $(0.23$ to $\left.0.55 \mathrm{nmol}_{\text {worm }}^{-1} \mathrm{~h}^{-1}, \mathrm{n}=2\right)$, Laxus oneistus $(0.15$ to $0.56 \mathrm{nmol}$ worm ${ }^{-1} \mathrm{~h}^{-1}, \mathrm{n}=3$ ), Eubostrichus dianae ( 0.16 to $0.55 \mathrm{nmol}^{-1} \mathrm{worm}^{-1} \mathrm{~h}^{-1}, \mathrm{n}=6$ ), and the symbiotic oligochaete Inanidrilus sp. (1.02 to $1.78 \mathrm{nmol}_{\text {worm }}^{-1}$ $\mathrm{h}^{-1}, \mathrm{n}=3$ ), whereas nitrite did not appear in incubations of the symbiotic nematode Eubostrichus parasitiferus $(n=7)$ and in nonsymbiotic worms $(n=19)$ (data not shown).

\section{Oxidation of thiols}

The concentrations of sulfide, thiosulfate and glutathione in the tissues of Stilbonema sp. decreased to about half after $24 \mathrm{~h}$ incubation in the absence of an externally provided thiol source (Table 2 ). When transferred to a medium containing sulfide, a statistically significant increase of internal sulfide and thiosulfate was observed (Student's $t$-test $p<0.05 \%$ ). The incubation in thiosulfate resulted in a significant increase of internal thiosulfate levels. In the presence of nitrate, only thiosulfate but not sulfide accumulated in the tissues. The internal glutathione levels decreased following any incubation condition compared to freshly collected animals. The thiol concentrations of aposymbiotic worms were significantly less than those of symbiotic animals. When aposymbiotic worms were transferred to sulfide-containing seawater there was a significant increase in internal sulfide and thiosulfate concentrations which was accompanied by the death of all experimental animals.

The internal thiol stores of Laxus oneistus behaved essentially the same in response to the incubation conditions as those of Stilbonema sp. (Table 3). The noticeable exception were the internal thiosulfate levels which did not drop following microoxic maintenance, reached highest levels after the sulfide + nitrate treatment and were higher in aposymbiotic worms than in symbiotic ones.

In Stilbonema sp., most of the sulfide $(78.1 \%)$ and thiosulfate $(76.6 \%)$ was present in the bacterial coat (Table 4). In contrast, in Laxus oneistus, less than half of the sulfide $(43 \%)$ and $0 \%$ of the thiosulfate was present in the bacterial coat. Aposymbiotic Stilbonema sp. and $L$. oneistus contained significantly less thiol concentrations in their tissues than nonsymbiotic worms from the same habitat (Fig. 4). 
Table 2. Stilbonema sp. Internal sulfide, thiosulfate, sulfate and glutathione concentrations. Values were determined in freshly collected animals, after $24 \mathrm{~h}$ maintenance in microoxic seawater (approx. 20\% oxygen saturation) and after subsequent incubation in anaerobic seawater containing different electron donors ( $200 \mu \mathrm{M}$ sulfide, $1 \mathrm{mM}$ thiosulfate) and acceptors ( $1 \mathrm{mM}$ nitrate). Internal thiol contents were also determined in aposymbiotic Stilbonema sp. which had been stripped of their symbiont coat and were treated as above (all values in $\mu$ mol $\mathrm{g}^{-1}$ wwt, $n=3$ to $7 \pm \mathrm{SD}$, except for sulfate, where $n=2$ ). nd: not determined. -Statistically significant difference compared to freshly collected Stilbonema sp.i " statistically significant difference compared to Stilbonema sp. maintained under microoxic conditions; ' 'statistically significant difference compared to freshly collected, aposymbiotic Stilbonemasp. (Student's t-test, unpaired, 2-tailed with $\mathrm{p}<0.05 \%$ )

\begin{tabular}{|c|c|c|c|c|}
\hline \multirow[t]{2}{*}{ Incubation condition } & \multicolumn{4}{|c|}{ Internal thiol concentrations ( $\mu \mathrm{mol} \mathrm{g} \mathrm{g}^{-1}$ wwt) } \\
\hline & Sulfide & Thiosulfate & Sulfate & Glutathione \\
\hline Freshly collected Stilbonema sp. & $0.56 \pm 0.15$ & $0.89 \pm 0.38$ & nd & $0.17 \pm 0.05$ \\
\hline After $24 \mathrm{~h}$ microoxic maintenance & $0.34 \pm 0.03$ & $0.37 \pm 0.03$ & $0.91 \pm 0.01$ & $0.11 \pm 0.02$ \\
\hline$\rightarrow$ Sulfide & $0.49 \pm 0.05^{*}$ & $1.01 \pm 0.16^{\circ}$ & $1.04 \pm 0.06$ & $0.04 \pm 0.05^{\circ}$ \\
\hline$\rightarrow$ Sulfide + nitrate & $0.41 \pm 0.06$ & $0.86 \pm 0.31$ & $0.79 \pm 0.04$ & $0.07 \pm 0.04^{\circ}$ \\
\hline$\rightarrow$ Thiosulfate & $0.41 \pm 0.07$ & $1.02 \pm 0.29 \cdots$ & $1.90 \pm 0.24^{\cdots}$ & $0.06 \pm 0.02^{\circ}$ \\
\hline$\rightarrow$ Thiosulfate + nitrate & $0.39 \pm 0.07$ & $1.46 \pm 0.8$ & $1.70 \pm 0.03$ & $0.08 \pm 0.01^{\circ}$ \\
\hline Freshly collected, aposymbiotic Stilbonema sp. & $0.19 \pm 0.06^{\circ}$ & $0.23 \pm 0.03^{\circ}$ & nd & $0.08 \pm 0.01$ \\
\hline After $24 \mathrm{~h}$ microoxic maintenance & $0.18 \pm 0.03$ & $0.3 \pm 0.12$ & $0.57 \pm 0.01$ & nd \\
\hline$\rightarrow$ Sulfide $^{t}$ & $0.56 \pm 0.17 \cdots$ & $1.21 \pm 0.75 \cdots$ & $1.67 \pm 0.11$ & $0.11 \pm 0.07$ \\
\hline${ }^{a}$ Note that all aposymbiotic worms were killed & & & & \\
\hline
\end{tabular}

\section{Worm recolonisation}

In Stilbonema sp., the bacterial flakes produced by sonification reattached to the cuticule in the form of patches. However, there were no signs indicating that the bacterial coat, once lost or partially stripped, could be re-grown. Small holes in an otherwise intact coat of symbionts showed no signs of closure over a period of $7 \mathrm{~d}$. Towards the end of $1 \mathrm{wk}$ incubation time, some specimens started to become overgrown with a different, heterogeneous bacteria population which did not show the characteristic organisation and uniformity of the symbiont coat. Therefore, these were taken as signs of deterioration of the animals. ratory reduction to ammonia). The energy yield using nitrate is less than with oxygen, but it is energetically superior to fermentation processes. It allows the bacteria to utilize the respiratory chain even under anaerobic conditions. Because nitrate is used as an alternative to oxygen, nitrate respiration is, with a few notable exceptions (Hentschel \& Felbeck 1995), an anaerobic process.

Our studies show that the symbionts of Stilbonema $\mathrm{sp}$. are capable of the respiratory reduction of nitrate and nitrite under anaerobic conditions. The fact that nitrate is not reduced quantitatively to nitrite (Fig. 1a) together with the disappearance of nitrite (Fig. 1b) shows that the symbionts are capable of denitrification,

\section{DISCUSSION}

\section{Metabolism of nitrogen}

The respiration of nitrate is a widespread phenomenon among bacteria, but has never been shown in higher organisms (Knowles 1982, Stewart 1988). In anaerobic respiration, nitrate or other inorganic electron acceptors (i.e. sulfate and iron) are used in the absence of oxygen as a terminal electron acceptor in the respiratory chain. Nitrate can be respired to nitrite (nitrate respiration) or further through other intermediates to nitrogen gas (denitrification) or to ammonia (respi-
Table 3. Laxus oneistus. Internal sulfide, thiosulfate, and glutathione contents (all values in $\mu \mathrm{mol} \mathrm{g}{ }^{-1}$ wwt, $\mathrm{n}=2$ to $4 \pm \mathrm{SD}$ ). nd: not determined. "Statistically significant difference compared to freshly collected Laxus oneistus; - statistically significant difference compared to Laxus oneistus maintained under microoxic conditions (Student's $t$-test, unpaired, 2 -tailed with $\mathrm{p}<0.05 \%$ )

\begin{tabular}{|c|c|c|c|}
\hline \multirow[b]{2}{*}{ Incubation condition } & \multicolumn{3}{|c|}{ Internal thiol concentrations ( $\left.\mu \mathrm{mol} \mathrm{g}{ }^{-1} w w t\right)$} \\
\hline & Sulfide & Thiosulfate & Glutathione \\
\hline Freshly collected Laxus oneistus & $0.70 \pm 0.06$ & $0.66 \pm 0.04$ & $0.13 \pm 0.03$ \\
\hline After 24 h microoxic maintenance & $0.40 \pm 0.03$ & $0.71 \pm 0.20$ & $0.10 \pm 0.03$ \\
\hline$\rightarrow$ Sulfide & $0.99 \pm 0.51 \cdots$ & $1.18 \pm 0.21 \cdots$ & $0.10 \pm 0.01$ \\
\hline$\rightarrow$ Sulfide + Nitrate & $0.53 \pm 0.13$ & $1.94 \pm 0.50^{\cdots}$ & $0.07 \pm 0.00$ \\
\hline$\rightarrow$ Thiosulfate & $0.55 \pm 0.08$ & $1.47 \pm 0.20^{\prime}$ & $0.07 \pm 0.01$ \\
\hline \multicolumn{4}{|l|}{ Freshly collected, symbiont-free } \\
\hline Laxus oneistus & $0.37 \pm 0.02^{\circ}$ & $0.82 \pm 0.04$ & $0.09 \pm 0.02$ \\
\hline After 24 h microoxic maintenance & 0.4 & 0.7 & nd \\
\hline
\end{tabular}


Table 4. Stilbonema sp and Laxus oneistus. Percentage of biomass, internal sulfide and thiosulfate concentration in aposymbiotic worms and in the respective bacterial fraction

\begin{tabular}{|c|c|c|c|c|}
\hline \multicolumn{2}{|c|}{ Nematode species } & \multirow{2}{*}{$\begin{array}{c}\text { Biomass } \\
(\%) \\
65.4\end{array}$} & \multirow{2}{*}{$\begin{array}{c}\text { Sulfide } \\
(\%)\end{array}$} & \multirow{2}{*}{$\begin{array}{c}\begin{array}{c}\text { Thiosulfate } \\
(\%)\end{array} \\
23.3\end{array}$} \\
\hline Stilbonema & Worms & & & \\
\hline & Symbionts & 34.6 & 78.1 & 76.6 \\
\hline \multirow[t]{2}{*}{ Laxus } & Worms & 86.4 & 56.7 & 100 \\
\hline & Symbionts & 13.3 & 43.3 & 0 \\
\hline
\end{tabular}

with nitrogen gas being a possible end product. The respiratory nature of this process is confirmed by its inhibition by azide and cyanide. Moreover, nitrate respiration is inhibited by oxygen which is another indication of the respiratory nature of this process.

When collected from their natural habitat, most worms have a 'shiny white' appearance whereas 'pale' worms are found much less frequently. In a similar symbiosis of the marine gutless oligochaete Inanidrilus leukodermatus (formerly Phallodrilus leukodermatus, Annelida), similar color differences have been correlated with the presence of energy-rich storage compounds, like polythionates and polyhydroxybutyrate (Giere et al. 1991). White worms gradually turn pale after $72 \mathrm{~h}$ exposure to aerated seawater, a process which could be reversed by subsequent incubation in sulfide-containing seawater. In our experiments, only white stilbonematid worms were capable of respiring nitrate in the absence of externally added thiols (Fig. 2). This suggests that the symbionts of white

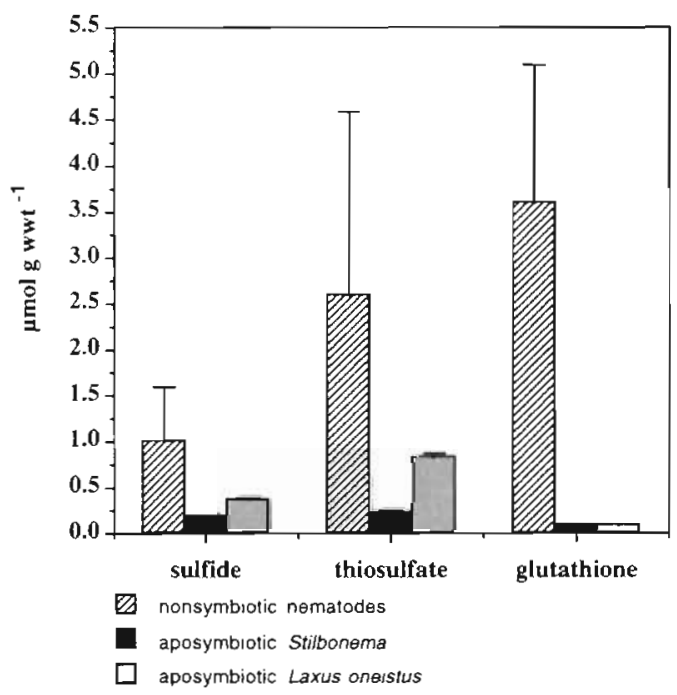

Fig. 4. Concentrations of sulfide, thiosulfate, and glutathione in nonsymbiotic nematodes in the tissues of aposymbiotic Stilbonema $\mathrm{sp}$, and aposymbiotic Laxus oneistus from the same habitat ( $\mu$ mol thiol $g^{-1}$ wwt, $n=3 \pm S E$ ) worms are able to utilize internal stores (elemental sulfur, polythionates) as electron donors for respiration, whereas pale worms are unable to respire nitrate for the lack of a suitable electron donor.

Nitrate respiration was not stimulated by sulfide or thiosulfate in Stilbonema worms (Fig. 3a). A possible explanation for this somewhat unexpected result could be that since only white worms were used for these experiments, further stimulation by externally provided thiols was not possible. A similar phenomenon has been observed in incubations of gills of the bivalve Lucinoma aequizonata in which nitrate respiration could only be stimulated by sulfide in black gills (lacking sulfur) but not in yellow gills (containing sulfur) (U. Hentschel unpubl.).

The symbionts of Laxus oneistus are also capable of respiring nitrate and nitrite. One noticeable difference from Stilbonema sp. is that nitrate respiration was stimulated by sulfide (Fig. $3 \mathrm{~b}$ ). It is conceivable that the symbionts of $L$. oneistus are more tolerant to higher sulfide concentrations. This hypothesis is supported by the observation that Laxus are typically found in areas of higher sulfide concentrations than Stilbonema sp. Alternatively, the data can be explained by physiological differences at the beginning of the experiment. Even though both species appeared white, they may not have been loaded with the same amounts of internal energy reserves.

The dissimilatory reduction of nitrate appears to be common in symbiotic meiofauna in sulfide-rich habitats since other, less abundant worms from the same habitat (Inanidrilus sp., Eubostrichus dianae) were shown to respire nitrate as well. Because very high concentrations of ammonia ( $980 \mu \mathrm{mol} \mathrm{g}^{-1}$ dry wt) had been measured previously in the tissues of Inanidrilus leukodermatus (Giere et al. 1991), ammonia could possibly be the end product of respiratory nitrate reduction in 1 . leukodermatus symbionts. Nitrate respiration/denitrification has also been demonstrated in chemoautotrophic symbionts of the bivalves Lucinoma aequizonata (Hentschel et al. 1993, Hentschel \& Felbeck 1995), Solemya reidi (Wilmot \& Vetter 1992, Hentschel unpubl. res.) and the deep-sea hydrothermal vent tubeworm Riftia pachyptila (Hentschel \& Felbeck 1993).

Several authors have noticed that while the majority of symbiotic nematodes and oligochaetes cluster around the RDP layer in their natural environment, a significant fraction of these animals is often found in the deeper anoxic sediment layers (Giere et al. 1982, 1991, Ott \& Novak 1989). This observation has led to the hypothesis, that the uptake and oxidation of sulfide must be temporarily uncoupled since oxygen is unavailable in the deeper sediments. Consequently, the presence of oxygen and sulfide storage systems 
was proposed (Meyers et al. 1987). In light of our findings that symbionts of 2 host species can oxidize sulfide under anaerobic conditions with nitrate as an electron acceptor, the occurrence of worms in anoxic sediments can be explained. It allows the worms to tap into the energy from sulfide-rich pockets located in the deeper sediment layers without being dependent on oxygen. Thus, it is not energy generation but the animal's tolerance to anaerobic exposure and sulfide toxicity that is the limiting factor for the survival in deeper, sulfidic sediments.

\section{Metabolism of sulfur}

There are 2 aspects of the biological processing of sulfide which need to be taken into consideration: the energy generation in bacterial respiration and the toxic effects of sulfide upon living organisms. The conclusion that these symbioses depend on sulfide for energy generation has been based on (1) the presence of key enzymes of sulfide oxidation, (2) the presence of elemental sulfur in tissues (Polz et al. 1992), (3) the accumulation of ${ }^{35} \mathrm{~S}$ in the bacterial coat of Eubostrichus sp. after incubation in $\mathrm{Na}_{2}{ }^{35} \mathrm{~S}$ (Powell et al. 1979) (4) the high sulfide concentrations in the habitat and, (5) the white 'sulfur like' appearance of symbionts (Schiemer et al. 1990). In this study we expanded on these results and measured, for the first time, thiol metabolism in live stilbonematid worms.

When Stilbonema sp. were incubated in the presence of thiols, a marked increase of internal sulfide and thiosulfate levels was observed, whereas in the absence of thiols during microoxic exposure the internal thiol contents decreased (Table 2). This correlation provides in vivo evidence that this symbiosis accumulates thiols from the environment. Further investigations are required to determine whether and to which extent these processses are linked to energy generation requires further investigations. The role of nitrate in this process was questionable as its presence resulted in a small, but statistically not significant increase compared to microoxic maintenance (Table 2). Also, nitrate respiration in Stilbonema sp. could not be stimulated by thiols (Fig. 3a). Therefore, the correlation between nitrate and thiol metabolism could not be adequately resolved.

Upon exposure of Laxus oneistus to thiols, the internal thiol concentrations increased essentially in the same pattern as was observed for Stilbonema sp. (Table 3). The noticeable exception was that the internal thiosulfate concentration remained unchanged during microoxic exposure. Since all thiosulfate in $L$. oneistus is located in the animal body and not in the bacteria (Table 4), it is likely that this thiosulfate pool is not available for oxidation by the bacteria. A second observation was that L. oneistus worms have higher concentrations of thiols in their body than Stilbonema sp. (Fig. 4, Table 4). This can possibly be related to the fact that the monolayer coat of $L$. oneistus is thinner than the mulitayer coat of Stilbonema sp. and may therefore provide a less efficient shield against thiol accumulation from the porewater.

Sulfur bacteria are known to reduce glutathione in combination with sulfide oxidation for energy generation purposes (Gottschalk 1986). Accordingly, when Stilbonema sp. were incubated in the presence of reduced sulfur substrates, the concentrations of internal glutathione decreased significantly (Table 2). Thus it is conceivable that the reduction of glutathione may also be due to bacterial metabolism and possibly, to energy generation processes. Approximately half of the glutathione of symbiotic Stilbonema sp. was found to reside in the worm. The concentrations, however, were low compared to those of nonsymbiotic nematodes from the same habitat (Fig. 4), to the GSH concentration of the nonsymbiotic marine polychaete Capitella sp. (1.4 $\mathrm{\mu mol} \mathrm{g}^{-1} \mathrm{wwt}$ ) and to the marine oligochaete Tubificoides benedii (0.4 $\mu_{\mathrm{mol} \mathrm{g}}^{-1}$ wwt) (Dubilier 1992).

Interestingly, the incubation of aposymbiotic Stilbonema sp. in $200 \mu \mathrm{M}$ sulfide resulted in the death of all animals, whereas this concentration did not affect the survival of symbiotic worms under the same experimental conditions (Table 2). Also, aposymbiotic worms survived fine in sulfide-free seawater for several days. With the death of the aposymbiotic animals upon exposure to sulfide, a relatively high accumulation of internal sulfide and thiosulfate was observed, possibly indicating that the aposymbiotic worms were killed by sulfide poisoning. Thus, an additional benefit of the bacteria to the worm becomes apparent. The bacterial coat may provide the worm with an efficient barrier to prevent sulfide poisoning. When the shield is removed, the worms may be killed by sulfide concentrations which are sublethal in symbiotic animals. The observation that freshly collected Stilbonema sp. and Laxus oneistus have much lower thiol concentrations in their bodies than nonsymbiotic nematodes from the same habitat supports the hypothesis that the bacteria provide a shield against sulfide poisoning.

\section{Metabolic rates}

The metabolic rates determined in this study fall within the range of activities measured in the marine symbiotic worm Inanidrilus leukodermatus (Table 1). This oligochaete of slightly larger size than the nematodes harbors extracellular, chemoautotrophic symbionts below its cuticule (Giere et al. 1982). The rates of sulfate 
excretion and $\mathrm{CO}_{2}$ fixation in this species amounted to $7.1 \mu \mathrm{mol} \mathrm{g}{ }^{-1} \mathrm{wwt} \mathrm{h}^{-1}$ (Giere et al. 1988) and $5 \mu \mathrm{mol} \mathrm{g}{ }^{-1}$ wwt $\mathrm{h}^{-1}$ respectively (Felbeck et al. 1983). The $\mathrm{O}_{2}$ respiration rates and $\mathrm{CO}_{2}$ fixation rates measured in our study were about $10 \times$ lower than in a microrespirometry study of individual Stilbonematinae $\left(24 \mu \mathrm{mol} \mathrm{O}_{2} \mathrm{~g}^{-1} \mathrm{wwt} \mathrm{h}^{-1}\right)$ and about 10 to 18 -fold lower than the $\mathrm{CO}_{2}$ fixation rates as determined by Schiemer et al. (1990).

\section{Bacteria-host interactions}

Our studies concerning a possible recolonisation process of aposymbiotic worms were stimulated by the finding that Laxus oneistus symbionts had a significantly higher division rate in areas where the coat was disturbed than in intact areas (Polz et al. 1992). In the present study we found no indication that a recolonization of an aposymbiotic worm or, at least, the repair of a disturbed bacterial coat was possible. Also, our attempts to culture the symbionts were unsuccessful. The rates of division observed by Polz et al. (1992) are probably too low to be detected in our experiments with the resolution power of a light microscope. Therefore it appears that even though this symbiotic system is potentially tractable owing to the extracellular location of the symbionts, specific problems like the symbiont culture or the recolonisation process are not trivial to address.

In conclusion, the results of the present study suggest that these symbioses resemble the chemoautotrophic symbioses from deep-sea hydrothermal vents and other reducing habitats in many ways including the biochemical and physiological properties of nitrogen and sulfur metabolism. In spite of the simpler organisation of this symbiosis, the interaction between host and bacteria appears to be very complex. Further studies are necessary to begin to unravel the mechanisms of interaction between chemoautotrophic bacteria and nematode hosts

Acknowledgements. We would like to thank the station managers R. Bright and N. Vrolijk for the excellent technical support while at Carrie Bow Cay and the laboratory of Prof Grieshaber for their help with the HPLC and IC analysis. This study was supported by grants to H.F. (National Science Foundation) and to J.A.O. (Fonds zur Förderung der wissenschaftlichen Forschung). This is contribution \# 568 , Caribbean Coral Reef Ecosystems Program, Smithsonian Institution Field Station on Carrie Bow Caye, Belize.

\section{LITERATURE CITED}

Berger E, Urbancik W, Ott JA (1996) Eubostrichus topiarius sp.n., a new free-living marine species of Stilbonematinae (Nematoda: Desmodoriae) from a shallow subtidal sand bottom. Nematologica $42.521-536$
Cline JD (1969) Spectrophotometric determination of hydrogen sulfide in natural waters. Limnol Oceanogr 14:454-458

Dubilier N (1992) Ökophysiologische und morphologische Anpasssungen des marinen Oligochaeten Tubificoides benedii (dUdekem) an Sauerstoffmangel und Sulfid. Dissertation zur Erlangung des Doktorgrades, University of Hamburg

Fahey RC Newton GL (1987) Determination of low-molecular-weight thiols using monobrombimane fluorescent labeling and high-performance liquid chromatography. Methods Enzymol 143:85-96

Felbeck H, Liebezeit G, Dawson R, Giere O (1983) $\mathrm{CO}_{2}$ fixation in tissues of marine oligochaetes (Phallodrilus leukodermatus and $P$. planus) containing symbiotic, chemoautotrophic bacteria. Mar Biol 75:187-191

Fenchel T, Riedl RJ (1970) The sulfide system: a new biotic community underneath the oxidized layer of marine sand bottoms. Mar Biol 7:255-268

Giere O, Liebezeit G, Dawson R (1982) Habitat conditions and distribution pattern of the gutless oligochaete Phallodrilus leukodermatus. Mar Ecol Prog Ser 8:291-299

Giere O, Wirsen CO. Schmidt C, Jannasch HW (1988) Contrasting effects of sulfide and thiosulfate on symbiotic $\mathrm{CO}_{2}$-assimilation of Phallodrilus leukodermatus (Annelida). Mar Biol 97:413-419

Giere O, Conway NM, Gastrock G, Schmidt C (1991) 'Regulation' of gutless annelid ecology by endosymbiotic bacteria. Mar Ecol Prog Ser 68:287-299

Gieskes J, Peretsman G (1986) Water-chemistry procedures aboard the Joides Resolution-some comments. Ocean drilling program, Texas A\&M University, Technical Note No. 5:1-46

Gottschalk G (1986) Chemolithotrophic and phototrophic metabolism. Bacterial metabolism. Springer-Verlag, New York, p 238-316

Hentschel U, Felbeck $H$ (1993) Nitrate respiration in the hydrothermal vent tube worm Riftia pachyptila. Nature (Lond) 366:338-340

Hentschel U, Felbeck H (1995) Nitrate respiration in chemoautotrophic symbionts of the bivalve Lucinoma aequizonata is not regulated by axygen. Appl Environ Microbiol 61:1630-1633

Hentschel U, Cary SC, Felbeck H (1993) Nitrate respiration in the chemoautotrophic symbionts of the bivalve Lucinoma aequizonata. Mar Ecol Prog Ser 94:35-41

Knowles R (1982) Denitrification. Microbiol Rev 46:43-70

Koop J (1994) Ion chromatography. Dissertation zur Erlangung des Doktorgrades, University of Düsseldorf

Meyers MB, Fossing $\mathrm{H}$, Powell EN (1987) Microdistribution of interstitial meiofauna, oxygen and sulfide gradients, and the tubes of macro-infauna. Mar Ecol Prog Ser 35:223-241

Ott JA, Novak R (1989) Living at an interface: meiofauna at the oxygen/sulfide boundary of marine sediments. In Ryland JS, Tyler PA (eds) Reproduction, genetics and distribution of marine organisms. Olsen \& Olsen, Fredensborg, p 415-422

Ott JA, Novak R, Schiemer F, Hentschel U, Nebelsick M, Polz $M$ (1991) Tackling the sulfide gradient: a novel strategy involving marine nematodes and chemoautotrophic ectosymbionts. PSZN I: Mar Ecol 12(3):261-279

Polz MF, Felbeck H, Novak R, Nebelsick M, Ott JA (1992) Chemoautotrophic, sulfur-oxidizing symbiotic bacteria on marine nematodes: morphological and biochemical characterization. Microb Ecol 24:313-329

Polz MF, Distel DL, Zarda B, Amann R, Felbeck H, Ott JA, Cavanaugh CM (1994) Phylogenetic analysis of a highly specific asssociation between ectosymbiotic, sulfur-oxidiz- 
ing bacteria and a marine nematode. Appl Environ Microbiol 60:4461-4467

Powell EN, Crenshaw MA, Rieger RM (1979) Adaptations to sulfide in the meiofauna of the sulfide system. I. ${ }^{35} \mathrm{~S}$-sulfide accumulation and the presence of a sulfide detoxification system. J Exp Mar Biol Ecol 37:57-76

Schiemer F, Novak R, Ott JA (1990) Metabolic studies on thiobiotic free-living nematodes and their symbiotic microorganisms. Mar Biol 106:129-137

Somero GN, Childress JJ, Anderson AE (1989) Transport, metabolism, and detoxification of hydrogen sulfide in animals from sulfide-rich marine environments. Crit Rev Aquat Sci 1(4):591-614

Editorial responsibility: Otto Kinne (Editor), Oldendorf/Luhe, Germany
Stewart V (1988) Nitrate respiration in relation to facultative metabolism in enterobacteria. Microbiol Rev 52: $190-232$

Vismann B (1991) Sulfide tolerance: physiological mechanisms and ecological implications. Ophelia 34:1-27

Wieser W (1959) Eine ungewöhnliche Assoziation zwischen Blaualgen und freilebenden marinen Nematoden. Österr Bot Zeitschr 106:81-87

Wieser W (1960) Benthic studies in Buzzards Bay II. The Meiofauna. Limnol Oceanogr 5:121-137

Wilmot DB, Vetter RD (1992) Oxygen- and nitrogen-dependent sulfur metabolism in the thiotrophic clam Solemya reidi. Biol Bull 182:444-453

Submitted: November 24, 1998; Accepted: February 15, 1999 Proofs received from author(s): May 26, 1999 